\title{
Influence of Various Weed Management Approaches on Weed Dynamics in Rice under Different Crop Establishment Methods
}

\author{
C.R. Netam ${ }^{1 *}$, Rameshwari Netam ${ }^{2}$, A. Qureshi ${ }^{3}$, Kunti Banjare ${ }^{4}$ and A.K. Netam ${ }^{3}$ \\ ${ }^{1}$ Department of Agronomy, College of Agriculture, G. B. Pant University of Agriculture and \\ Technology, Pantnagr, U.S. Nagar (Uttarakhand), India \\ ${ }^{2}$ Department of Seed Certification, Government of Chhattisgarh, India \\ ${ }^{3}$ College of Agriculture \& Research Station, Kanker, Chhattisgarh, India \\ ${ }^{4}$ Scientist, KVK Bemetara, Chhattisgarh, India
}

*Corresponding author

A B S T R A C T

\section{Keywords \\ Crop establishment methods, Weed management, Weed dynamics, Rice \\ Article Info \\ Accepted: \\ 12 February 2018 \\ Available Online: \\ 10 March 2018}

\begin{abstract}
A field experiment was conducted for two consecutive rainy seasons of 2011 and 2012 at G. B. Pant University of Agriculture and Technology, Pantnagar, U.S. Nagar (Uttarakhand) to evaluate the "Influence of various weed management approaches on weed dynamics in rice under different crop establishment methods". The results revealed that the lowest density and dry matter of total weeds at 60 days after sowing/days after transplanting was obtained with transplanted rice. This treatment produced the highest number of panicles $/ \mathrm{m}^{2}$ and rice grain yield (4145 and $3879 \mathrm{~kg} / \mathrm{ha}$ ). Among the weed management practices, application of bispyribac sodium $20 \mathrm{~g} / \mathrm{ha}$ at $15 \mathrm{DAS} / \mathrm{DAT}$ followed by one hand weeding at 35 DAS/DAT recorded the minimum population and dry matter of total weeds and recorded the highest weed control efficiency which showed at par results with the application of bispyribac sodium $22.5 \mathrm{~g} / \mathrm{ha}$ at 2-3 leaf stage of weeds followed by one HW at 35 DAS/DAT. This treatment produced the significantly higher number of panicles $/ \mathrm{m}^{2}$, grains/panicle and grain yield.
\end{abstract}

\section{Introduction}

In India, rice is the staple food for millions of people and plays a vital role in the economy. It is generally grown by transplanting in puddled soil. Weeds are regarded as one of the major limiting factors of the crop production. Weeds share light, nutrients and water with the crop and thus, interfere with rice growth and production in many ways. The effective control of weeds at initial stages (0-40 DAT) can help in improving productivity of the crop.
There are various factors responsible for low productivity of rice, in which weeds are predominant ones. In India, transplanting is the most common method of rice cultivation. However, owing to its several limitations viz; more labour and time consuming and requiring a lot of expenditure on raising nursery, it's uprooting and transplanting. In wet seeding, sowing of pre-germinated or sprouted seeds on puddled soil reduce substantially the cost of labour as it eliminates the excess use of seedlings and related 
operations such as seedling nursery operation, care of seedlings, pulling, bundling, transportation and transplanting (Serrano, 1975). Sometimes farmers do not get chance for weeding at appropriate time due to preoccupation. Hand weeding in wet seeded rice is more time consuming, cumbersome and not as easy as in transplanted rice (Moody, 1983). Direct dry seeded rice (DSR) which excludes puddling and drudgery of transplanting the young rice seedlings provide an option to resolve the edaphic conflict and enhance the sustainability of rice-wheat cropping system. Transplanted rice has deleterious effects on the soil environment for the succeeding wheat and other upland crops. Puddling requires lot of scarce water at a time when there is little water in the reservoirs, destroys soil structure and adversely affects soil productivity. Non-development of ground water in kharif, late onset of monsoon and drudgery of operations often delays rice transplanting which leads to late vacation of fields, forcing farmers to sow wheat after the optimum time. DSR facilitates timely establishment of rice and succeeding winter crops. Unlike puddled fields, DSR fields do not crack and thus, help in saving irrigation water (Kumar, 2009).

Farmers growing direct seeded rice are likely to encounter greater problems related to weed management in absence of standing water. The transition to direct seeding of rice can, therefore, be successful only if accompanied by effective weed management practices (Singh et al., 2003). Weeds cause 50-60 per cent grain yield reduction in puddled conditions and 91 per cent in un-puddled conditions (Ali and Sankaran, 1984). The use of weeding tools damage the rice as they move through the field, especially during early crop growth, and they also fail to remove some of the grassy weeds. Keeping these facts in view, the present investigation was undertaken to study the effect of crop establishment methods and weed management practices on weed dynamics and productivity of rice.

\section{Materials and Methods}

The field experiments was conducted in Norman E. Borlaug Crop Research Centre, Govind Ballabh Pant University of Agriculture and Technology, Pantnagar, U.S. Nagar (Uttarakhand) during two Rainy seasons of 2011and 2012. The soil of the experimental field was loam in texture. The soil was found high in organic carbon $(0.87 \%)$, low in available nitrogen (262.0 $\mathrm{kg} / \mathrm{ha}$ ), medium in available phosphorus (21.8 $\mathrm{kg} / \mathrm{ha})$ and potassium $(259.0 \mathrm{~kg} / \mathrm{ha})$ content with neutral $\mathrm{pH}$ (7.2). An experiment was conducted in split plot design with three replications; keeping rice establishment methods viz., direct dry seeded rice (DSR), wet seeded rice (WSR- sprouted seeds) and transplanted rice (TPR) in main plots and six levels of weed management practices viz. penoxsulam $22.5 \mathrm{~g} / \mathrm{ha}$ at 2-3 leaf stage of weeds, penoxsulam $22.5 \mathrm{~g} / \mathrm{ha}$ at 2-3 leaf stage of weeds followed by ( $\mathrm{fb}$ ) one hand weeding (HW) at 35DAS/DAT, bispyribac sodium 20 $\mathrm{g} / \mathrm{ha}$ at 15DAS/DAT, bispyribac sodium 20 $\mathrm{g} / \mathrm{ha}$ at 15DAS/DAT fb one hand weeding at 35DAS/DAT, weed free and weedy check in sub plot.

In direct dry seeded rice, seeds were sown in lines $20 \mathrm{~cm}$ apart by using $40 \mathrm{~kg} / \mathrm{ha}$ seed rate and covered by soil; while, sprouted seeds were sown in rows $20 \mathrm{~cm}$ apart in wet seeded rice by using manually operated drum seeder. Twenty one day old seedlings were transplanted in transplanting method and cultivar Sarju-52 was used in experiment. In direct dry seeding rice seed was sown on 11 June, 2011 and 21 June, 2012 during first and second year, respectively. Seed was water soaked for wet seeding and nursery raising for transplanting to same date of seed sown in direct dry seeding. Crop was fertilized 
uniformly with 150:60:40 kg/ha of $\mathrm{N}, \mathrm{P}_{2} \mathrm{O}_{5}$ and $\mathrm{K}_{2} \mathrm{O}$, respectively through the use of NPK mixture (12:32:16), urea (46:0:0) and muriate of potash (0:0:60). Total amount of phosphorus was applied through NPK mixture while, nitrogen through NPK mixture and urea and potassium through NPK mixture and muriate of potash. The full amount of phosphorus and potassium and half dose of nitrogen were applied as basal just before sowing of rice seed/transplanting of rice seedling. Remaining half of the nitrogen was top dressed through urea in two splits; first at active tillering and second at panicle initiation stage in all methods of rice establishment.

Density and dry matter of weeds were recorded at 60 DAS/DAT days after seeding with the help of quadrate $(0.5 \times 0.5 \mathrm{~m})$ and then converted in per square meter. Data on weeds were subjected to square root transformation before statistical analysis to normalize their distribution. All the data were analyzed by using ANOVA, and the least significant difference (LSD) value at 5\% level of significance were calculated and used to test significant differences between treatment means.

\section{Results and Discussion}

\section{Total weed density}

The experimental field was infested with grassy weeds, viz. Echinochloa colona, Echinochloa crusgalli, Cynodon dactylon, Panicum repens and Paspalum distichum; broad-leaved weeds, viz. Ammania baccifera, Eclipta alba, Caesulia axillaris, Commelina benghalensis, Euphorbia hirta and Ludwigia parviflora; and sedges, viz. Cyperusiria, Cyperus difformis and Fimbristylis miliaceae. Method of rice transplanting significantly influenced the weed density at 60 DAT (Table 1). The lower weed density was recorded under Transplanted Rice, which was significantly superior to Direct Seeded Rice. This might be due to effective control of all categories of weeds during intensive puddling, which was started two weeks before transplanting and sufficient time allowed for germination of weed seeds present in the soil.

Amongst weed management methods, lower density of grasses, broad-leaved weeds and sedges at60 DAT and higher weed control efficiency (Table 1, 3) was recorded with Bispyribac sodium $20 \mathrm{~g} / \mathrm{ha} \mathrm{fb}$ one $\mathrm{HW}$ at 35 DAS/DAT followed by Penoxsulam $22.5 \mathrm{~g} / \mathrm{ha}$ $\mathrm{fb}$ one HW at $35 \mathrm{DAS} / \mathrm{DAT}$.

Bispyribac sodium $20 \mathrm{~g} / \mathrm{ha}$ at 15 DAS/DAT fb one $\mathrm{HW}$ at 35 DAS/DAT followed by Bispyribac sodium $20 \mathrm{~g} / \mathrm{ha}$ at $15 \mathrm{DAS} / \mathrm{DAT}$ had significantly lower broad-leaved weeds and sedges and higher weed control efficiency as compared to the Penoxsulam $22.5 \mathrm{~g} / \mathrm{ha}$ at 23 leaf stage of weeds $\mathrm{fb}$ one $\mathrm{HW}$ at 35 DAS/DAT followed by Penoxsulam22.5 g/ha at 2-3 leaf stage of weeds at 60 DAT. This was due to integration of chemical and mechanical method of weed control resulting in broad-spectrum control of weeds, reported by Mukherjee and Maity (2011).

\section{Effect on rice growth}

In case of rice transplanting methods, transplanting rice recorded significantly higher plant height $(\mathrm{cm})$, No. of shoots $(\mathrm{cm})$, Crop dry matter $\left(\mathrm{g} \mathrm{m}^{-2}\right)$, dry matter accumulation and leaf area index as compared to Direct seeded rice (Table 2). It might be due to low crop weed competition on growth attributes in transplanting rice as compared to direct seeded rice. Amongst weed control methods, Bispyribac sodium $20 \mathrm{~g} / \mathrm{ha} \mathrm{fb}$ one HW followed by Penoxsulam $22.5 \mathrm{~g} / \mathrm{ha}$ fb one HW recorded significantly higher plant height, no. of tillers/hill, dry matter accumulation and leaf area index. 
Table.1 Effect of crop establishment methods and weed management practices on weed density at 60DAS/DAT (Pooled mean of 2 years)

\begin{tabular}{|l|}
\hline Treatment \\
\hline Rice establishment method \\
\hline Direct seeded rice \\
\hline Wet seeded rice \\
\hline Transplanted rice \\
\hline SEm \pm \\
\hline LSD (P=0.05) \\
\hline Weed management practice \\
\hline Penoxsulam $22.5 \mathrm{~g} / \mathrm{ha}$ \\
\hline Penoxsulam $22.5 \mathrm{~g} / \mathrm{ha}$ fb one HW at 35 DAS/DAT \\
\hline Bispyribac sodium $20 \mathrm{~g} / \mathrm{ha}$ \\
\hline Bispyribac sodium $20 \mathrm{~g} / \mathrm{ha}$ fb one HW at 35 DAS/DAT \\
\hline Weed free \\
\hline Weedy check \\
\hline SEm \pm \\
\hline LSD (P=0.05) \\
\hline
\end{tabular}

\begin{tabular}{|c|c|c|c|}
\hline \multicolumn{3}{|c|}{ Weed density $\left(\mathbf{n o} / \mathbf{m}^{2}\right)$} & \multicolumn{2}{c|}{ Total weed density $\left(\mathbf{n o} / \mathrm{m}^{2}\right)$} \\
\hline Grasses & Broad-leaved weeds & Sedges & \\
\hline $6.67(74.7)$ & $3.49(15.2)$ & $4.15(22.9)$ & $3.7(126.0)$ \\
\hline $5.4(38.6)$ & $2.28(9.4)$ & $3.5(15.9)$ & $3.3(73.1)$ \\
\hline $4.48(26.8)$ & $1.96(7.8)$ & $2.6(10.8)$ & $2.8(51.7)$ \\
\hline 0.28 & 0.21 & 0.48 & 0.08 \\
\hline 1.1 & 0.31 & NS & 0.33 \\
\hline $7.8(48.2)$ & & & $4.4(84.3)$ \\
\hline $3.88(11.1)$ & $3.39(10.4)$ & $4.25(13.8)$ & $2.6(16.0)$ \\
\hline $7.43(43.6)$ & $0.66(1.8)$ & $0.54(1.3)$ & $4.4(89.4)$ \\
\hline $3.23(8.5)$ & $4.06(13.3)$ & $4.88(18.4)$ & $2.6(15.6)$ \\
\hline 0 & $0.99(2.4)$ & $1.03(2.67)$ & 0 \\
\hline $12.11(353.1)$ & 0 & 0 & $5.7(297.8)$ \\
\hline 0.46 & $6.3(36.9)$ & $8.7(58.7)$ & 0.14 \\
\hline 1.33 & 0.54 & 0.52 & 0.40 \\
\hline
\end{tabular}

Original values given in parentheses, DAS- Days after sowing, DAT- Days after transplanting, fb- followed by, HW- hand weeding, NS- Non-significant

Table.2 Effect of crop establishment methods and weed management practices on growth attributes in rice at 60DAS/ DAT (Pooled mean of 2 years)

\begin{tabular}{|c|c|c|c|c|}
\hline Treatment & Plant height (cm) & Number of shoots $\left(\mathrm{m}^{-2}\right)$ & Crop dry matter ( $\left.\mathrm{g} \mathrm{m}^{-2}\right)$ & Leaf Area Index \\
\hline \multicolumn{5}{|l|}{ Rice establishment method } \\
\hline Direct seeded rice & 69.87 & 216 & 297.24 & 3.50 \\
\hline Wet seeded rice & 71.62 & 238 & 327.81 & 3.68 \\
\hline Transplanted rice & 71.56 & 244 & 334.29 & 3.77 \\
\hline SEm \pm & 0.45 & 3.58 & 4.92 & 0.07 \\
\hline LSD $(P=0.05)$ & NS & 13.99 & 19.25 & NS \\
\hline \multicolumn{5}{|l|}{ Weed management practice } \\
\hline Penoxsulam $22.5 \mathrm{~g} / \mathrm{ha}$ & 69.59 & 209 & 282.79 & 3.31 \\
\hline Penoxsulam 22.5 g/ha fb one HW & 73.40 & 286 & 394.56 & 4.31 \\
\hline Bispyribac sodium $20 \mathrm{~g} / \mathrm{ha}$ & 70.72 & 208 & 280.92 & 3.31 \\
\hline Bispyribac sodium $20 \mathrm{~g} / \mathrm{ha}$ fb one HW & 73.62 & 286 & 395.02 & 4.31 \\
\hline Weed free & 75.36 & 298 & 418.53 & 4.37 \\
\hline Weedy check & 63.70 & 109 & 146.84 & 2.28 \\
\hline SEm \pm & 0.69 & 6.54 & 8.97 & 0.19 \\
\hline LSD $(P=0.05)$ & 2.0 & 18.90 & 25.89 & 0.55 \\
\hline
\end{tabular}

DAS- Days after sowing, DAT- Days after transplanting, fb- followed by, HW- hand weeding, NS- Non-significant 
Table.3 Effect of crop establishment methods and weed management practices on yield attributes, yield, weed index and weed control efficiency (Pooled mean of 2 years)

\begin{tabular}{|c|c|c|c|c|c|c|c|}
\hline \multirow[t]{2}{*}{ Treatment } & \multicolumn{4}{|c|}{ Yield attributes } & \multirow{2}{*}{$\begin{array}{l}\text { Grain } \\
\text { yield } \\
\text { (t/ha) }\end{array}$} & \multirow{2}{*}{$\begin{array}{l}\text { Weed } \\
\text { index } \\
(\%)\end{array}$} & \multirow{2}{*}{$\begin{array}{l}\text { Weed control } \\
\text { efficiency }(\%)\end{array}$} \\
\hline & $\begin{array}{l}\text { Number of } \\
\text { panicles } / \mathrm{m}^{2}\end{array}$ & $\begin{array}{l}\text { Panicle } \\
\text { length (cm) }\end{array}$ & $\begin{array}{l}\text { Grains/ } \\
\text { panicle }\end{array}$ & $\begin{array}{l}\text { Test weight } \\
\text { (g/1000 seeds) }\end{array}$ & & & \\
\hline \multicolumn{8}{|l|}{ Rice establishment methods } \\
\hline Direct seeded rice & 174.42 & 25.04 & 154.44 & 23.49 & 3.30 & 34.73 & 75.95 \\
\hline Wet seeded rice & 197.47 & 25.19 & 156.36 & 23.66 & 3.61 & 29.79 & 76.35 \\
\hline Transplanted rice & 218.36 & 25.43 & 158.72 & 23.76 & 4.01 & 23.61 & 76.95 \\
\hline SEm \pm & 2.05 & 0.29 & 0.82 & 0.13 & 0.06 & 1.30 & 0.50 \\
\hline $\mathrm{CD}(\mathrm{P}=0.05)$ & 8.02 & NS & 3.21 & NS & 0.22 & & NS \\
\hline \multicolumn{8}{|l|}{ Weed management practices } \\
\hline $\begin{array}{l}\text { Penoxsulam } 22.5 \mathrm{~g} / \mathrm{ha} \text { at } 2-3 \text { leaf stage } \\
\text { of weeds }\end{array}$ & 157.39 & 24.77 & 152.33 & 23.33 & 2.90 & 43.70 & 80.00 \\
\hline $\begin{array}{l}\text { Penoxsulam } 22.5 \mathrm{~g} / \mathrm{ha} \text { at } 2-3 \text { leaf stage } \\
\text { of weedsfb one HW at } 35 \text { DAS/DAT }\end{array}$ & 262.00 & 25.80 & 162.33 & 23.91 & 4.86 & 5.54 & 99.00 \\
\hline $\begin{array}{l}\text { Bispyribac sodium } 20 \mathrm{~g} / \mathrm{ha} \text { at } 15 \\
\text { DAS/DAT }\end{array}$ & 159.56 & 24.73 & 152.11 & 23.61 & 2.91 & 43.32 & 80.25 \\
\hline $\begin{array}{l}\text { Bispyribac sodium } 20 \text { g/ha at } 15 \\
\text { DAS/DAT fb one HW at } 35 \text { DAS/DAT }\end{array}$ & 264.28 & 25.66 & 163.67 & 23.91 & 4.92 & 5.18 & 99.05 \\
\hline Weed free & 277.83 & 26.03 & 167.72 & 24.08 & 5.14 & 0.00 & 100.00 \\
\hline Weedy check & 59.44 & 24.32 & 139.61 & 22.98 & 1.11 & 78.52 & 0.00 \\
\hline SEm \pm & 5.58 & 0.50 & 1.98 & 0.21 & 0.09 & 1.39 & 0.66 \\
\hline LSD $(P=0.05)$ & 16.10 & NS & 5.71 & NS & 0.25 & 4.01 & 1.87 \\
\hline
\end{tabular}

DAS- Days after sowing, DAT- Days after transplanting, fb- followed by, HW- hand weeding, NS- Non-significant 
This might be due to comparatively less weed competition for nutrients, and better weed control. resulted in significantly higher plant height, no. of tillers/hill, and dry matter accumulation and leaf area index in comparison to conventional scheduling of nitrogen. The significant variations in growth attributes were observed due to nitrogen application when needed by crop as observed by Islam et al., (2009).

\section{Rice yield and weed control efficiency}

The differences in 1000-grain weight were non-significant due to rice transplanting method. Transplanted rice had significantly higher number of panicles/hill, no. of grains/panicle and higher grain yield as compared to direct seeded rice (Table3). Higher values of yield attributes and grain yield under transplanted rice were perhaps due to better partitioning of photosynthates from source to sink as a result of lower cropweed competition owing to favourable growing conditions in transplanting rice. The results were corroborated with the findings of Jaiswal and Singh (2001).Amongst weed control treatments, Bispyribac sodium $20 \mathrm{~g} / \mathrm{ha}$ at $15 \mathrm{DAS} / \mathrm{DAT}$ fb one $\mathrm{HW}$ at $35 \mathrm{DAS} / \mathrm{DAT}$ followed by Penoxsulam22.5 g/ha at 2-3 leaf stage of weeds $\mathrm{fb}$ one $\mathrm{HW}$ at 35 DAS/DAT had significantly more 1000 -grain weight, no. of panicles/ hill, no. of grains/panicle and grain yield. This might be due to effective control of weeds which in turn significantly increased the no. of panicles/hill and grains/panicle consequently improving the grain yield. Control of weeds by herbicides during early stages of rice followed by Penoxsulam $22.5 \mathrm{~g} / \mathrm{ha}$ at 2-3 leaf stage of weeds fb one HW at 35 DAS/DAT resulted in lower competition for growth resources that influenced the crop to grow better as evidenced in increased yield attributes. Similar findings were also observed by Singh et al., (2005) and Ramachandra et al., (2012).
Resulted in significantly more 1000-grain weight, no. of panicles/hill, grains/panicle and grain yield in comparison to conventional scheduling of nitrogen application. Higher values of yield attributes and grain yield were probably owing to more utilization and uptake of nitrogen at active growing stages, viz. tillering and panicle initiation. Similar findings were also observed by Awas the (2009) and Gill and Walia (2013).It can be concluded that Bispyribac sodium $20 \mathrm{~g} / \mathrm{ha}$ at $15 \mathrm{DAS} / \mathrm{DAT} \mathrm{fb}$ one $\mathrm{HW}$ at $35 \mathrm{DAS} / \mathrm{DAT}$ followed by Penoxsulam22.5 g/ha at 2-3 leaf stage of weeds $\mathrm{fb}$ one HW at 35 DAS/DAT, under transplanting could be recommended for effective weed management and higher rice yield.

\section{References}

Ali, M. A. and Sankaran, S. 1984. Crop-weed competition in direct seeded low land and upland bunded rice. Indian J. Weed Sci.16: 90-96.

Awasthe R. 2009. Nitrogen management in transplanted rice (Oryza sativa) in midhill acidic soils of Sikkim Himalayas. Indian Journal of Agronomy 54(1): 4751.

Combination with metsulfuron-methyl on weed control in transplanted rice. Mysore Journal of Agricultural Sciences 44(2): 246-254.

Gill JS and Walia SS. 2013. Effect of establishment methods and nitrogen levels on basmati rice (Oryza sativa). Indian Journal of Agronomy 58(4): 506511.

Islam MS, Hasanuzzaman $\mathrm{R}$ and Nahar K. 2009. Effect of split application of $\mathrm{N}$ fertilizer on morpho-physiological parameters of rice genotypes. International Journal of Plant Production 3(1): 51-62.

Jaiswal VP and Singh GR. 2001.Effect of planting methods, source and level of 
nitrogen on the growth and yield of rice (Oryza sativa) and on succeeding wheat (Triticum aestivum). Indian Journal of Agronomy 46(1): 5-11.

Kumar, $\mathrm{R}$. 2009. http://agropedia.iitk.ac.in/?q=content/dir ect-seeded-rice (Submitted by shuklarajeew on Tue, 30/06/2009 16:57).

Moody, K. 1983. The status of weed control in rice in Asia. In Proceeding in Women in Rice Farming. International Rice Research Institue, Los Banos, Laguna, Philippines. pp 467-480.

Mukerjee, P. K., and Maithy, S. K. 2011. Weed control in transplanted and wet seeded rainy season rice. Indian $\mathrm{J}$. Agric. Sci. 81(2):134-139.

Ramchandra, C., Denesh, G. R. and Sydanwarulla 2010. Weed management practices in transplanted rice by using glyphosate. Biennial Conference on "Recent Advances in Weed Science Research -2010”, February 25-26, 2010,
Indira Gandhi Krishi Vishwavidyalaya, Raipur (CG). 63p.

Serrano, F. B. 1975. Twenty-six Years of Rice Research and Development. National Research Council of the Philippines, Diliman, Quezon City, Philippines, 122p.

Singh, G., Singh, V. P., Singh, V., Singh, S. P., Kumar, A., Mortimer, M. and Johnson, D. E. 2005. Characterization of weed flora and weeds management practices in rice under different cropping systems in Western Gangetic plains of India. Indian J. Weed Sci., 37(1\&2): 45-50.

Singh, G., Singh, Y., Sing, V. P., Singh, R. K., Singh, Pratibha; Johnson, D. E., Mortimer, M., and Orr. A. 2003. Direct seeding as an alternative to transplanting rice for the rice - wheat system of the Indo-gangetic plains. Sustainability issues related to weed management. Proc. BCPC Conferencecrop science and technology. F-9: pp 1035-1040.

\section{How to cite this article:}

Netam, C.R., Rameshwari Netam, A. Qureshi, Kunti Banjare and Netam, A.K. 2018. Influence of Various Weed Management Approaches on Weed Dynamics in Rice under Different Crop Establishment Methods. Int.J.Curr.Microbiol.App.Sci. 7(03): 1551-1557. doi: https://doi.org/10.20546/ijcmas.2018.703.185 